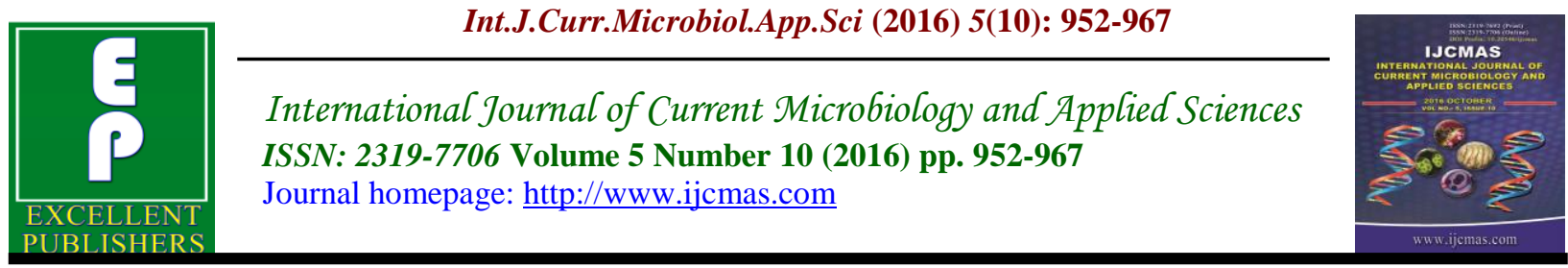

Original Research Article

http://dx.doi.org/10.20546/ijcmas.2016.510.102

\title{
The Role of Tinospora cordifolia in Extenuating the Toxic Effects of CPF on Hepatic Modifications along with Electron Microscope observations in Red Blood Cells
}

\author{
Kanika Aggarwal* and Devinder Singh \\ Department of Zoology and Environmental Sciences, Punjabi University, \\ Patiala 147002, Punjab, India \\ *Corresponding author
}

\begin{abstract}
A B S T R A C T
Keywords

Antioxidant, Chloropyrifos, Scanning Electron Microscopy, Hepatotoxicity, Tinospora cordifolia.

Article Info

Accepted:

28 September 2016 Available Online: 10 October 2016

This study investigates the role of Tinospora cordifolia (TC) extract against liver damage induced in male albino rat by an Organophosphorus (OP) insecticide, Chloropyrifos (CPF). Liver damage was investigated by various parameters like Lipid peroxidation (LPO), Superoxide dismutase (SOD), Catalase, Glutathione reductase (GR), Lactate dehydrogenase (LDH), Acid phosphatase, $\mathrm{Na}^{+} / \mathrm{K}^{+}$ATPase and Acetyl cholinesterase (AChE) and Scanning Electron microscope (SEM) observation on blood cells. Group I Control group, Group II $30 \mathrm{mg} / \mathrm{kg}$ CPF b. wt., Group III TC 1.0 g/kg b. wt. with $30 \mathrm{mg} / \mathrm{kg} \mathrm{CPF} \mathrm{b.} \mathrm{wt.,} \mathrm{Group} \mathrm{IV} \mathrm{TC} 2.0$ g/kg b.wt. with $30 \mathrm{mg} / \mathrm{kg}$ CPF b. wt., Group V TC $4.0 \mathrm{~g} / \mathrm{kg}$ b.wt. with $30 \mathrm{mg} / \mathrm{kg}$ CPF b. wt. and Group VI $4.0 \mathrm{~g} / \mathrm{kg}$ b.wt. of TC were administered orally via gavages. The results showed that TC overcome the CPF induced decreased levels of SOD, Catalase, Glutathione reductase, LDH, Acid Phosphatase, $\mathrm{Na}^{+} / \mathrm{K}^{+}$ATPase and AChE compare to CPF control. Moreover, TC significantly decreased the LPO level induced by CPF as compared to CPF control. The drastic alterations in the shape of the blood cells were reverted significantly with the increasing doses concentration of TC. Therefore, it could be concluded that TC administration is useful in routine therapy for protection against tissue damage induced by CPF.
\end{abstract}

\section{Introduction}

Chloropyrifos (CPF) is one of the world's most widely used Organophosphorus insecticide to control a variety of pests in agriculture and animal farms because of its quick action, comparatively shorter half life and poor accumulation in the food web (Leaberry, 1986; Kwong, 2002). The toxicity of $\mathrm{CPF}$ has been attributed due to its initial metabolite, the CPF oxon. The oxon targets Acetylcholinesterase (AChE) by binding to the active site and inactivating the AChE enzyme leads to neuropathy (Amitai et al., 1998). It has been shown that repeated administration of $\mathrm{CPF}$ caused significant hepatic atrophy (Miyazaki and Hodgson 1972). Although the primary toxicological target sites of CPF are the central nervous system, its toxicological manifestation is very commonly observed in other organs as well including the liver. Previous reports 
have demonstrated the toxic effect of $\mathrm{CPF}$ on hepatic tissue, wherein, the profile of liver marker enzymes, antioxidant enzymes and essential trace elements were found to adversely affect the CPF intoxicated rats (Goel et al., 2005).

TC is a common climbing shrub which is used for the treatment of snake bite and leprosy and is also prescribed in general debility, diabetes, fever, jaundice, skin diseases, rheumatism, urinary diseases, dyspepsia, gout, gonorrhoea and leucorrhoea. It is a constituent of several ayurvedic preparations like guduchayadochurna, gududyadikwath, guduchilouha, amritarista, sanjivanivati, guduchitaila and amiritastakkwath. The extracts of TC have shown significant decrease in the blood glucose like insulin, without affecting total lipid levels in normal rabbits and in alloxan induced diabetic rabbits (Wadood et al., 1989). The efficacy of TC extract in patients of allergic rhinitis has also been assessed (Badar et al., 2005).

Stanely et al., (1999) reports about antidiabetic and antioxidant effect of and found $\mathrm{TC}$ is more effective than glibenclamide. Moreover, TC has also found to exerted greatest anticancer activity on tumor cells by reducing the GSH concentration and increase in LPx was investigated by Jagetia et al., (1998). Goel et al., (2004) suggested that the extract of TC has radio protective manifestation in several systems of experimental animals.

Nagarkatti et al., (1994) showed the improvement in activity of Kupffer cells in rats treated with TC. Singh et al., (2006) found increases in sulfhydryl (-SH) and cytochrome $\mathrm{P}(450)$ and enzyme activities of cytochrome $\mathrm{P}(450)$ reductase, cytochrome b(5) reductase, GST, DTD, SOD, catalase, GSH peroxidase (GPX) and GR, with TC against carcinogen mice in hepatic tissue.
TC extract partially reduced the elevated LPO, alkaline phosphatase and glutamine pyruvate transaminase in serum and liver in in vitro studies (Mathew and Kuttan, 2003). TC extract has been shown to have hepato protective and immune stimulant effects in carbon tetrachloride $\left(\mathrm{CCl}_{4}\right)$ intoxicated rat (Bishayi et al., 2002).

Therefore, the present study was designed to evaluate the hepatoprotective and neuroprotective potential (in terms of $\mathrm{AChE}$ activity) of TC against $\mathrm{CPF}$ administered rat liver with the aim to understand its benefits through attenuation of oxidative stress. The effect of TC on CPF induced alterations of some enzymatic and non enzymatic parameters such as LPO and activities of AChE, SOD, Catalase, Glutathione reductase, $\mathrm{LDH}$, Acid phosphatase, $\mathrm{Na}^{+}-\mathrm{K}^{+}-$ ATPase in rat liver were studied including morphological changes in blood cells with the help of SEM.

\section{Materials and Methods}

\section{Chemicals}

$\mathrm{CPF}$ and TC were procured from Meghmani Organics Limited and Himalaya Drug Company, Bangalore (India) respectively. All other chemicals used in the present study were of analytical grade and were purchased from various chemical suppliers.

\section{Animals and Treatment}

Adult male wistar rats, weighing 120- $180 \mathrm{~g}$ each were obtained from the central animal house of Panjab University, Chandigarh. The animals were housed in clean polypropylene cages and were fed standard diet ad libitum (Ashirwad Industries). The animals were allowed to acclimatize to the local vivarium for 7 days. They had free access to water on a $12 \mathrm{~h}$ light/dark cycle. 
The experimental protocols were approved by the Institutional Animal Ethic Committee (IAEC). The rats were randomly segregated into following groups with a group having 6 animals each.

- Group I Control group (Vehicle treated): Animals were administered corn oil only.

- Group II (CPF treated): Animals were administered with $30 \mathrm{mg} / \mathrm{kg}$ CPF b. wt./day, for 28 days.

- Group III (TC + CPF treated): Animals were administered with $1.0 \mathrm{~g} / \mathrm{kg}$ TC b. wt. along with $30 \mathrm{mg} / \mathrm{kg} \mathrm{CPF} \mathrm{b.} \mathrm{wt.} \mathrm{daily} \mathrm{for}$ 28 days.

- Group IV (TC + CPF treated): Animals were administered with $2.0 \mathrm{~g} / \mathrm{kg}$ TC b. wt. along with b. wt. daily for 28 days.

- Group V (TC + CPF treated): Animals were administered with $4.0 \mathrm{~g} / \mathrm{kg}$ TC b. wt. along with $30 \mathrm{mg} / \mathrm{kg} \mathrm{CPF} \mathrm{b.} \mathrm{wt.} \mathrm{daily} \mathrm{for}$ 28 days.

- Group VI (TC treated): Animals were administered daily with $4.0 \mathrm{~g} / \mathrm{kg}$ TC b. wt. only for 28 days.

\section{Induction of Hepatotoxicity by CPF}

TC was administered as a suspension of powder prepared in $10 \mathrm{ml}$ of double distilled water. The dose of CPF used in the study was with reference to the $\mathrm{LD}^{50}$ value of $\mathrm{CPF}$ and based on doses reported in literature, which was also standardized in the laboratory. TC administration doses concentration was also finalized with the most effective ones in different research papers. CPF doses were administered to the animals as reported in the earlier report from our lab (Aggarwal and Singh 2011; Aggarwal et al., 2014). After 28 days of treatment, animals were fasted overnight and sacrificed by cervical decapitation under light ether anesthesia. Their hepatic tissues were removed, rinsed with ice cold $0.9 \%$ (w/v) normal saline and stored at $-80{ }^{\circ} \mathrm{C}$ for further analysis.

\section{Preparation of Homogenate}

A $10 \%(w / v)$ tissue homogenate was prepared in $50 \mathrm{mM}$ TrisHCl (pH 7.4) using Potter-Elvehjem glass homogenizer. Post nuclear supernatant was prepared by centrifuging the homogenate at $1000 \mathrm{x} \mathrm{g}$ for 10 minutes at $4{ }^{\circ} \mathrm{C}$ and then the supernatant was again centrifuged at $12,000 \times \mathrm{g}$ for 20 minutes at $4{ }^{\circ} \mathrm{C}$ for post mitochondrial supernatant (PMS). Various biochemical assays were performed with the supernatant.

Lipid peroxidation (LPO) was assayed according to the method of Buege and Aust (1978). The molar extinction coefficient for MDA is 1.56 x $105 \mathrm{M}-1 \mathrm{~cm}-1$. The results were expressed as nmoles of MDA formed $\min ^{-1} \mathrm{mg}^{-1}$ protein.

Superoxide dismutase (SOD) activity was assayed in the post mitochondrial supernatant according to the method of Kono (1978). The results were expressed as units/mg protein, where one unit of enzyme is defined as the amount of enzyme inhibiting the rate of reaction by $50 \%$.

Catalase activity was assayed in the post mitochondrial supernatant by the method of Luck (1971). Results of Catalase activity were expressed as $\mu$ moles of $\mathrm{H}_{2} \mathrm{O}_{2}$ decomposed $/ \mathrm{min} / \mathrm{mg}$ protein, using molar extinction coefficient of $\mathrm{H}_{2} \mathrm{O}_{2}\left(71 \mathrm{M}^{-1} \mathrm{~cm}^{-1}\right)$.

Glutathione reductase (GR) enzyme activity was measured in the post mitochondrial supernatant by the method of Horn (1971). Results were expressed as 
nmoles of NADPH oxidized/ $\mathrm{min} / \mathrm{mg}$ protein, using molar extinction coefficient of NADPH $\left(6.22 \times 10^{6} \mathrm{M}^{-1} \mathrm{~cm}^{1}\right)$.

Lactate dehydrogenase (LDH) activity was assayed spectrophotometrically in the post mitochondrial supernatant by the method of Schatz and Segal (1969). Results were expressed as $\mu$ moles of NADH oxidized $/ \mathrm{min} / \mathrm{mg}$ protein. The extinction coefficient $\left(6.3 \times 10^{3} \mu \mathrm{molL}^{-1} \mathrm{~min}^{-1}\right)$ was used to calculate the enzyme activity.

Acid phosphatase activity was assayed in the post mitochondrial supernatant by the method reported by Linhart and Walter (1965). The results were expressed as $\mu$ moles phenol produced $\mathrm{min}^{-1} \mathrm{mg}^{-1}$ protein.

$\mathrm{Na}^{+} / \mathrm{K}^{+}$-ATPase activity was measured according to the method of Quigley and Gotterer (1969). The $\mathrm{Na}^{+}-\mathrm{K}^{+}$-ATPase activity was computed by substracting the oubain insensitive ATPase from the total ATPase. The results were expressed as nmoles of ATP hydrolysed $/ \mathrm{min}^{-1} \mathrm{mg}^{-1}$ protein.

Acetyl cholinesterase (AChE) activity was determined in the homogenate according to the method of Ellman et al., (1961). The results were expressed as nmoles of Acetylthiocholine iodide hydrolyzed $/ \mathrm{min} / \mathrm{mg}$ protein. The extinction coefficient of 5-thio-2-nitrobenzoic acid $\left(13.6 \times 10^{3} \mathrm{M}^{-1} \mathrm{~cm}^{-1}\right)$ was used to calculate the enzyme activity.

Estimation of Protein content was done according to the method of Lowry et al. (1951) using BSA as a standard.

\section{Scanning Electron microscopy of blood cells}

Red blood cells were drawn from the animals belonging to each of the treatment groups, A drop of blood was fixed in $2.5 \%$ glutar aldehyde made in $0.2 \mathrm{M}$ phosphate

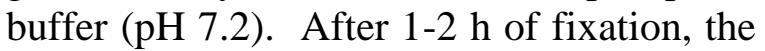
cells were separated by centrifugation at 1000- $1500 \mathrm{rpm}$. The fixative was discarded and the pellet was resuspended in the phosphate buffer. This process was repeated two times and the final pellet was suspended in minimum amount of triple distilled water. A drop of sample was smeared on the metallic SEM stubs, which were loaded with a conductive silver tape on its top. These stubs were then coated with gold to a thickness of $100 \mathrm{~A}^{\circ}$ using sputter ion coater with gold source for 4-5 $\mathrm{min}$. These specimens were finally observed under electron microscope (JSM-6100, Jeol, Japan) at Regional Sophisticated Instrumentation Center (RSIC), Panjab University, Chandigarh, India.

\section{Statistical Analysis}

All values were expressed as mean \pm standard deviation of six observations. Data were analyzed using one way analysis of variance (ANOVA). Values with $\mathrm{p} \leq 0.05$ were considered as statistically significant

\section{Results and Discussion}

\section{Effect of TC on CPF induced alterations in SOD, Catalase and GR activity}

CPF exposure significantly decreases the SOD activity to $38.50 \%$ in group II in comparison with control group. Further, TC administration minimized the effect of $\mathrm{CPF}$ in all the TC + CPF groups. The increase in the activity of SOD was highly significant and it was increased to $54.58 \%$ in group III, $80.16 \%$ in group IV, $91.62 \%$ in group V and $96.21 \%$ in group VI, when compared with the CPF treated group (Table 1).

Catalase activity significantly decreased to $31.84 \%$ in group II in comparison to the 
control group. TC administration along with CPF significantly increased the Catalase activity among all the groups to $62.20 \%$ in group III, $75.20 \%$ in group IV, $87.60 \%$ in group V and $114.14 \%$ in group VI, when compared to the CPF treated group (Table $1)$.

TC administration decreased the effect of $\mathrm{CPF}$ in all the $\mathrm{TC}+\mathrm{CPF}$ groups. $\mathrm{CPF}$ exposure significantly decreased the GR activity to $14.20 \%$ in group II in comparison with control group. The increase in the activity of GR after TC treatment was highly significant and it was $38.90 \%$ in group III, $60.40 \%$ in group IV, $101.20 \%$ in group V and $101.43 \%$ in group VI, when compared with the CPF treated group (Table 1).

\section{Effect of TC on CPF induced alterations in LPO}

CPF administration caused significant increase in LPO levels by $43 \%$. A significant decrease in LPO was observed and it was $33.55 \%$ in group $\mathrm{V}$ and $53.54 \%$ in group VI, when compared to the CPF treated group. TC showed ameliorating effects on CPF induced increase in LPO (Table 2).

\section{Effect of TC on CPF induced alterations in $\mathrm{LDH}$ activity}

Hepatic LDH activity reduced to statistically significant limits in the CPF treated group. $\mathrm{CPF}$ exposure significantly decreased the $\mathrm{LDH}$ activity to $15.50 \%$ in group II in comparison with control group. TC administration decreased the effect of $\mathrm{CPF}$ in all the $\mathrm{TC}+\mathrm{CPF}$ groups. The increase in the activity of LDH was highly significant and it was $53.4 \%$ in group III, $66.60 \%$ in group IV, $89.3 \%$ in group V and $79.20 \%$ in group VI, when compared to the CPF treated group (Table 3 ).
Effect of TC on CPF induced alterations in Acid Phosphatase activity

TC administration decreased the effect of $\mathrm{CPF}$ in all the $\mathrm{TC}+\mathrm{CPF}$ groups. $\mathrm{CPF}$ exposure significantly decreased the Acid phosphatase activity to $53.08 \%$ in group II in comparison with control group. The increase in the activity of Acid phosphatase was highly significant and it was $70.20 \%$ in group IV, $98.40 \%$ in group V and $109.78 \%$ in group VI, but increase in acid phosphatase was not significant in case of group III (57.60\%), when compared to the CPF treated group (Table 3).

\section{Effect of TC on CPF induced alterations in of $\mathrm{Na}^{+} / \mathrm{K}^{+} \mathrm{ATPase}$ activity}

TC treatment along with $\mathrm{CPF}$ reduced the effect of CPF. CPF exposure significantly decreased the $\mathrm{Na}+\mathrm{K}+$ ATPase activity to $39.80 \%$ in group II in comparison with control group. The increase in enzyme activity was $62.60 \%$ in group III, $78.70 \%$ in group IV, $93.90 \%$ in group V and $173.08 \%$ in group VI, when compared to the CPF treated group (Table 3 ).

\section{Effect of TC on CPF induced alterations in of $\mathrm{AChE}$ activity}

CPF exposure significantly decreased the AchE activity to $25.80 \%$ in group II in comparison with control group. TC resulted in partial recovery of AchE activity to $42.6 \%$ in group III, $52.40 \%$ in group IV, $62.10 \%$ in group V and $68.10 \%$ in group VI, when compared to the $\mathrm{CPF}$ treated group (Table 3).

\section{Scanning Electron Microscopic observations of red blood cells}

Morphological studies of the red blood cells were performed using Scanning Electron 
Microscope and results are depicted in Fig. $1 \mathrm{~A}-1 \mathrm{G}$. The control group showed typical appearance where most of the cells were perfect discocytes (Fig. 1B). Group II animals showed marked alterations in the morphological appearance of the cells (Fig. 1C \& 1D) with almost no normal discocytes. Most of the cells changed either to cup shaped stomatocytes or rounded spherocytes. Certain irregular and contracted cells with numerous projections called echinocytes were also seen. Numerous acanthocytes were also visible.

Protective effects of TC were also observed in combined TC and CPF treated groups. The drastic alterations in the shape of the blood cells were reverted significantly with the increase in the dose concentration of TC in Group III, IV and V (Fig. 1E, 1F \& 1G) to the normal appearance of the cells. TC treated control group (Group VI), had almost normal discocytes (Fig. 1A).

SOD, Catalase and GR enzymes are most sensitive to hepatotoxicity. LPO, $\mathrm{Na}^{+} / \mathrm{K}^{+}$ ATPase and Acetylcholine esterase are membrane bound enzymes. CPF causes complete blockage of $\mathrm{LDH}$ and Acid phosphatase at lethal dosage, which causes mortality in rodents.

The SOD- Catalase system provides the first defense against oxygen toxicity. The concentration of $\mathrm{H}_{2} \mathrm{O}_{2}$ directly regulates the catalase activity (Fornazier et al., 2002). SOD is responsible for catalyzing the conversion of superoxide anions into hydrogen peroxide (Liochev and Fridovich, 2003). In the present study, the improvement in SOD activity was found to be $53.12 \%$ which is corroborate by Verma et al., (2007) in hepatic tissue of rat and by El-Shenawy et al., (2010) who studied the effect of an organophosphate and Vitamin E as antidote. Various experimental studies involving CPF administration have shown inhibition of SOD activity in rat liver (Mansour and Mossa, 2010; Khalifa et al., 2011). CPF also decreased SOD activity compared with the control group in rat erythrocytes (Demir et al., 2011; Barski et al., 2011; Saxena et al., 2011).

TC decreased CPF toxicity by increasing the SOD activity. Similar work has been done by Stanely et al., (1999) in which antidote used was TC against the diabetes rat model instead of CPF as used in the present study. Antioxidant properties of TC have been supported by various experimental studies in which oxidative stress is created by different toxicants (Stanely et al., 1999; Stanely et al., 2000; Singh et al., 2006).

Catalase is a ubiquitous enzyme found in all known organisms and is a major primary antioxidant defence component which catalyzes the decomposition of $\mathrm{H}_{2} \mathrm{O}_{2}$ to $\mathrm{H}_{2} \mathrm{O}$ and $\mathrm{O}_{2}$ (Chelikani et al., 2004). In the present study, the improvement in catalase activity was found to be $55.76 \%$ which is substantiate by Verma et al. (2007) in hepatic tissue of rat and Yonar et al. (2012) in hepatic tissue of fish. There are numerous studies have been done by various researchers using different organs with comparable results (Mansour and Mossa 2009; El-Shenawy et al., 2010; Mansour and Mossa 2010; Demir et al., 2011; Shittu et al., 2012; Attia et al., 2012).

TC showed its ameliorating effects on CPF induced decrease in catalase activity. The present results are in accordance with the previous studies (Singh et al., 2006). TC showed the ameliorating effects on CPF induced decrease in GR activity. These results are corroborated with the previous studies (Singh et al., 2006). The increase in antioxidant enzymes SOD, Catalase and GR activity might be due to an increase in levels 
of glutathione and vitamin $\mathrm{C}$ by $\mathrm{TC}$ plant extract, which are natural antioxidants and being antioxidants enhanced the catalase activity (Stanely et al., 1999; Stanely et al., 2000).

As GSH is required for the activity of glutathione peroxidase to produce water and oxygen from $\mathrm{H}_{2} \mathrm{O}_{2}$, GR is an important enzyme required for maintaining high GSH/GSSG ratio (Carlberg and Mannervik 1985). In the present study, the improvement in GR activity was found to be $87 \%$ and the study is supported by Elsharkawy et al., (2012) and Khan et al., (2005) with CPF and different antidotes. The CPF exposure resulted in the decrease in GR activity in hepatic tissue in rats in the earlier studies also (Wu et al., 2011).

LPO is the process of oxidative deterioration of polyunsaturated fatty acids due to generation of reactive oxygen species under stress conditions (Niki et al., 1988). In the present study, the increase in LPO was observed and there are several studies done by various researchers on different organs with similar results (Verma et al., 2007; Mansour and Mossa, 2009; ElShenawy et al., 2010; Mansour and Mossa, 2010; Demir et al., 2011; Shittu et al., 2012; Attia et al., 2012). TC showed ameliorating effects on CPF induced increase in LPO. The present results are in accordance with the previous studies (Singh et al., 2006). Decrease in LPO by TC is due to its antioxidant properties (Stanely et al., 1999; Stanely et al., 2000; Goel et al., 2002; Subramanian et al., 2002; Shivananjappa and Muralidhara 2012). The increased LPO by $\mathrm{CPF}$ might be due to free radical mediated membrane damage.

In the present study, the improvement in LDH activity due of TC has been found to be $73.8 \%$. Decrease in level of LDH has been reported when fishes were exposed to
OPs (Goel et al., 2005; Heikal et al., 2013). TC showed the ameliorating effects on CPF induced decrease in LDH activity. The present results are in accordance with the previous studies done by various researchers (Stanely et al., 1999; Stanely et al., 2000; Goel et al., 2002; Subramanian et al., 2002; Singh et al., 2006; Shivananjappa and Muralidhara 2012). This might be due to decrease in LPO, by which LDH is retained in the cells and not leaked out in blood. $\mathrm{LDH}$ leakage in the hepatocytes in incubation medium on pesticide exposure was observed by Yamano and Morita (1992). It suggests that aerobic metabolism plays vital role in $\mathrm{CPF}$ induced toxicity, which results in the increased ATP production to meet energy requirement of the cells as energy store got depleted.

The leakage of LDH enzyme from hepatic tissue is the diagnostic marker of hepatic toxicity. Thus, the estimation of $\mathrm{LDH}$ is a useful parameter for assessing hepatic damage. When hepatic cells, containing $\mathrm{LDH}$ are damaged or destroyed due to deficient oxygen supply, production of free radicals and LPO leads to loss of the integrity of cell membranes and renders the membrane more porous and permeable. The membrane may even rupture, resulting in the leakage of this enzyme. This accounts for the decreased activities of LDH in hepatic tissue of CPF challenged rats.

In the present study, the decrease in Acid phosphatase activity was found because of CPF toxicity. Other studies also reported decrease in level of Acid phosphatase, when exposed to OPs (Thenmozhi et al., 2011). These researchers explained that the active sites of enzyme are directly attacked by ROS. The decline in the activities of antioxidant defense enzymes and enhanced LPO level imply that CPF would have induced the generation of oxygen free 
radicals, which peroxidize the lipid component of hepatic membrane. Bagchi and Stohs (1993) supported this with lindane induced generation of ROS, which enhanced LPO and decreased membrane fluidity. The recovery in the level of acid phosphatase is due to the protective role of TC against ROS on the antioxidant defense system and the decreased LPO as found earlier. The present results are in accordance with the previous studies done by various researchers (Stanely et al., 1999; Stanely et al., 2000, Goel et al., 2002; Subramanian et al., 2002; Singh et al., 2006; Shivananjappa and Muralidhara, 2012).

The improvement in $\mathrm{Na}^{+} / \mathrm{K}^{+}$ATPase activity was found to be $54.1 \%$. A similar study was reported by Amara et al., (2011). Similar research has been done by other researchers showing that the administration of various OPs inhibits $\mathrm{Na}+\mathrm{K}+$ ATPase in different tissues (Agrahari and Gopal 2008). $\mathrm{Na}^{+} / \mathrm{K}^{+}$ATPase is inactivated by LPO (Sun 1972; Hexum and Fried 1979). Mishra et al. (1989) have shown that LPO decreased the affinity of $\mathrm{Na}^{+} / \mathrm{K}^{+}$ATPase $\mathrm{Na}^{+}$and $\mathrm{K}^{+}$ions as the active site of enzyme directly attacked by ROS. Siesm et al. (2000) also suggested that oxidative products inhibit $\mathrm{Na}^{+} / \mathrm{K}^{+}$ATPase activity. These researchers explained that the active sites of enzymes are directly attacked by ROS. The decline in the activities of antioxidant defense enzymes and enhanced LPO level imply that $\mathrm{CPF}$ would have induced the generation of oxygen free radicals, which peroxidize the lipid component of hepatic membrane. Bagchi and Stohs (1993) supported this with lindane induced generation of ROS, which enhanced LPO and decreased membrane fluidity. The recovery of $\mathrm{Na}^{+} / \mathrm{K}^{+}$ATPase is due to the protective role of TC against ROS on the antioxidant defence system and the decreased LPO as found earlier in the present study.
The activity of Acetylcholine esterase is increased from $25.8 \%$ (CPF) to $42.6 \%$, $52.4 \%$ and $62.1 \%$ for TC. In the present study, the improvement in Acetylcholine esterase activity was found to be $36.3 \%$. Similar work has been done by various researchers with similar results (Mansour and Mossa, 2009; Mansour and Mossa, 2010; Diab et al., 2012). Acetylcholine esterase catalyzes the hydrolysis of neurotransmitter acetylcholine (Fukuto, 1990; Richardson 1995). There is hyper excitation of postsynaptic neurons by muscuranic or nicotinic acetyl choline receptors (Taylor et al., 1990). It was suggested with experimental studies that CPF is metabolically activated by oxidative desulfuration to CPF oxon (Chamber and Chamber 1989). Due to lipophilic nature of $\mathrm{CPF}$, it produces sustained inhibition of serum and liver acetylcholine esterase and causes delayed toxicity by getting sequestered with gradual discharge from the adipose tissues (Chambers and Carr 1993).

Chronic and sub chronic doses of OPs result in the development of tolerance due to the down regulation of the muscarinic (Costa et al., 1982) and nicotinic receptor (Costa and Murphy 1983) as an adaptive mechanism to the neurotransmitter levels. The decrease in Acetylcholine esterase activity in the present study might be due to phosphorylation of serine at the active site of enzyme. Supplementation by TC improved the CPF inhibited acetylcholine esterase activity to a limited extent. These results suggest that decrease in acetylcholine esterase activity might be partially due to peroxidation of membrane lipids by $\mathrm{CPF}$ and partial protection by TC can be attributed to their antioxidant action.

The administration of $\mathrm{CPF}$ resulted in prominent morphological changes in rat erythrocytes. 
Table.1 The effect of in vivo administration of CPF, varing doses of TC $+\mathrm{CPF}$ and TC alone for a period of 28 days daily on the activities of SOD, Catalase and GR in the liver of male Wistar rats

\begin{tabular}{|c|c|c|c|c|}
\hline Groups & Treatment & $\begin{array}{l}\text { SOD } \\
\text { ACTIVITY } \\
\text { (I.U.) }\end{array}$ & $\begin{array}{l}\text { Catalase }\left(\mu \text { moles } \mathrm{H}_{2} \mathrm{O}_{2}\right. \\
\text { decomposed } / \mathrm{min} / \mathrm{mg} \\
\text { protein) }\end{array}$ & $\begin{array}{l}\text { G.Reductase } \\
\text { ( } \mu \mathrm{M} \text { NADPH/ } \\
\text { min/mg protein) }\end{array}$ \\
\hline I & Control & $8.72 \pm 0.11$ & $34.29 \pm 1.38$ & $91.90 \pm 0.49$ \\
\hline II & $30 \mathrm{mg} / \mathrm{Kg}$ CPF B.Wt & $3.36 \pm 0.03^{* \#}$ & $10.92 \pm 0.03^{* \#}$ & $13.05 \pm 0.06^{* \#}$ \\
\hline III & $\begin{array}{l}\text { 1g/Kg TC B.Wt }+30 \mathrm{mg} \\
/ \mathrm{Kg} \text { CPF B.Wt }\end{array}$ & $\begin{array}{l}4.76 \pm \\
0.35^{*} \text { \$\# } \\
\end{array}$ & $21.35 \pm 0.74^{* \# \#}$ & $35.84 \pm 2.35^{* \$ \#}$ \\
\hline IV & $\begin{array}{l}2 \mathrm{~g} / \mathrm{Kg} \text { TC B.Wt }+30 \mathrm{mg} \\
/ \mathrm{Kg} \text { CPF B.Wt }\end{array}$ & $\begin{array}{l}6.99 \pm \\
0.36^{* \$ \#}\end{array}$ & $25.82 \pm 1.15^{* \#}$ & $55.55 \pm 2.31 *^{\$ \#}$ \\
\hline $\mathrm{V}$ & $\begin{array}{l}4 \mathrm{~g} / \mathrm{Kg} \text { TC B.Wt }+30 \mathrm{mg} \\
/ \mathrm{Kg} \text { CPF B.Wt }\end{array}$ & $7.99 \pm 0.33^{* \$}$ & $30.07 \pm 0.91 *^{\$ \#}$ & $93.08 \pm 4.57^{\$}$ \\
\hline VI & $4 \mathrm{~g} / \mathrm{Kg}$ TC B.Wt & $\begin{array}{ll}8.39 & \stackrel{ \pm}{ \pm} \\
& 0.19^{\$}\end{array}$ & $39.14 \pm 1.27 *^{\$}$ & $93.22 \pm 2.29^{\$}$ \\
\hline
\end{tabular}

Values are mean \pm S.D. of 6 animals in each group. $\mathrm{p} \leq 0.05$ was considered significant. ${ }^{*}$ Significantly different from control group $\left({ }^{*} \mathrm{p} \leq 0.05\right)$. ${ }^{\$}$ Significantly different from $30 \mathrm{mg} \mathrm{CPF} / \mathrm{Kg} \mathrm{B}$. Wt. group $\left.{ }^{\$} \mathrm{p} \leq 0.05\right)$. \# Significantly different from $4 \mathrm{~g}$ TC/Kg B.Wt group $\left({ }^{\#} \mathrm{p} \leq 0.05\right)$.

Table.2 The effect of in vivo administration of CPF, varing doses of TC $+\mathrm{CPF}$ and $\mathrm{TC}$ alone for a period of 28 days daily on LPO in the liver of male Wistar rats

\begin{tabular}{|c|l|c|}
\hline Group & Treatment & $\begin{array}{c}\text { LPO } \\
\text { (nmol MDA/mg } \\
\text { protein) }\end{array}$ \\
\hline I & Control & $3.41 \pm 0.27$ \\
\hline II & $30 \mathrm{mg} / \mathrm{Kg} \mathrm{CPF} \mathrm{B.Wt}$ & $5.37 \pm 0.0 *^{\#}$ \\
\hline III & $\begin{array}{l}1 \mathrm{~g} / \mathrm{Kg} \mathrm{TC} \mathrm{B.Wt}+30 \\
\mathrm{mg} / \mathrm{Kg} \mathrm{CPF} \mathrm{B.Wt}\end{array}$ & $7.37 \pm 1.65^{\text {*\# }}$ \\
\hline IV & $\begin{array}{l}2 \mathrm{~g} / \mathrm{Kg} \mathrm{TC} \mathrm{B.Wt}+30 \\
\mathrm{mg} / \mathrm{Kg} \mathrm{CPF} \mathrm{B.Wt}\end{array}$ & $5.33 \pm 0.49^{* \#}$ \\
\hline V & $\begin{array}{l}4 \mathrm{~g} / \mathrm{Kg} \mathrm{TC} \mathrm{B.Wt}+30 \\
\mathrm{mg} / \mathrm{Kg} \text { CPF B.Wt }\end{array}$ & $3.57 \pm 0.48^{\$}$ \\
\hline VI & $4 \mathrm{~g} / \mathrm{Kg} \mathrm{TC} \mathrm{B.Wt}$ & $2.49 \pm 0.1^{\$}$ \\
\hline
\end{tabular}

Values are mean \pm S.D. of 6 animals in each group. $\mathrm{p} \leq 0.05$ was considered significant.

${ }^{*}$ Significantly different from control group $\left({ }^{*} \mathrm{p} \leq 0.05\right)$.

${ }^{\$}$ Significantly different from $30 \mathrm{mg} \mathrm{CPF/Kg} \mathrm{B.} \mathrm{Wt.} \mathrm{group}\left({ }^{\$} \mathrm{p} \leq 0.05\right)$.

${ }^{\#}$ Significantly different from $4 \mathrm{~g}$ TC/Kg B.Wt group $\left({ }^{\#} \mathrm{p} \leq 0.05\right)$. 
Fig.1 Scanning Electron Micrograph of erythrocytes (Bar scale $=10 \mu \mathrm{m})$ in $4 \mathrm{~g} / \mathrm{Kg}$ TC group (A), Control group (B), $30 \mathrm{mg} / \mathrm{Kg}$ CPF group (C), (D), $1 \mathrm{~g} / \mathrm{Kg} \mathrm{TC}+30 \mathrm{mg} / \mathrm{Kg}$ CPF group (E), $2.0 \mathrm{~g} / \mathrm{Kg} \mathrm{TC}+30 \mathrm{mg} / \mathrm{Kg}$ CPF group (F) , 4g/Kg TC $+30 \mathrm{mg} / \mathrm{Kg}$ CPF group $(\mathrm{G})$
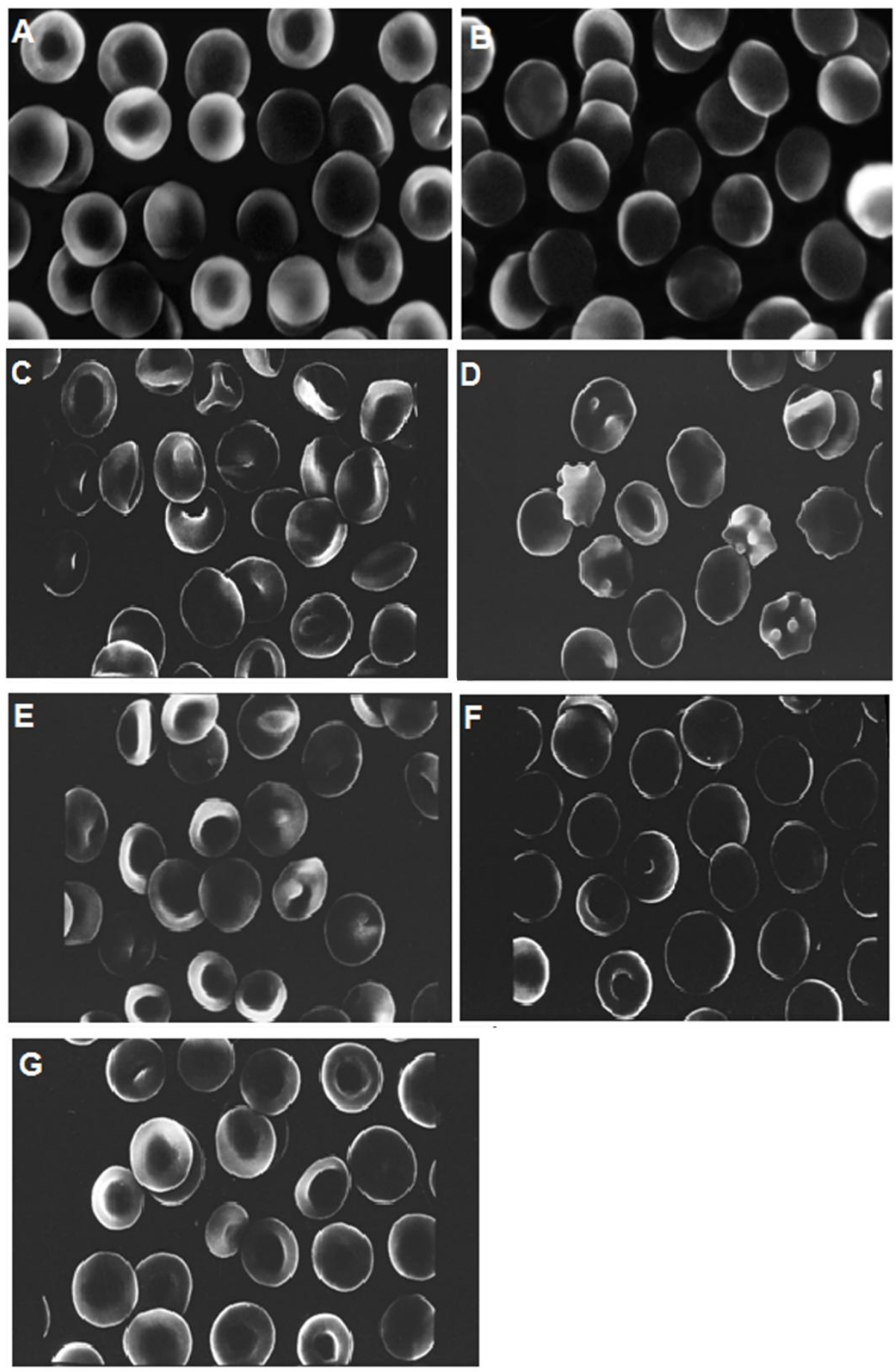
Table.3 The effect of in vivo administration of CPF, various doses of TC $+\mathrm{CPF}$ and $\mathrm{TC}$ alone for a period of 28 days daily on LDH, Acid Phosphatase, $\mathrm{Na} / \mathrm{K}+$ ATPase and Acetylcholine

Esterase activity in the liver of male Wistar rats

\begin{tabular}{|c|c|c|c|c|c|}
\hline Group & Treatment & $\begin{array}{c}\text { LDH activity } \\
\text { (nmol pyruvate } \\
\text { liberated/min/mg } \\
\text { protein) }\end{array}$ & $\begin{array}{c}\text { Acid } \\
\text { Phosphatase } \\
\text { (nmoles } / \mathrm{min} / \mathrm{mg} \\
\text { protein) }\end{array}$ & $\begin{array}{c}\mathbf{N a}^{+} / \mathbf{K}^{+} \\
\text {ATPase } \\
\text { (nmol of } \\
\mathrm{Pi} / \mathrm{min} / \mathrm{mg} \\
\text { protein) }\end{array}$ & $\begin{array}{c}\text { AChE } \\
(\mathrm{nmol} / \mathrm{min} / \mathrm{mg} \\
\text { protein) }\end{array}$ \\
\hline $\mathrm{I}$ & Control & $7.31 \pm 1.18$ & $11.85 \pm 0.82$ & $66.02 \pm 4.1$ & $26.93 \pm 0.58$ \\
\hline II & $\begin{array}{l}30 \mathrm{mg} / \mathrm{Kg} \mathrm{CPF} \\
\text { B.Wt }\end{array}$ & $1.14 \pm 0.01{ }^{* \#}$ & $6.29 \pm 0.16^{* \#}$ & $\begin{array}{l}26.33 \pm \\
1.34 * \#\end{array}$ & $6.96 \pm 1.01{ }^{* \#}$ \\
\hline III & $\begin{array}{l}1 \mathrm{~g} / \mathrm{Kg} \text { TC B.Wt } \\
+30 \mathrm{mg} / \mathrm{Kg} \mathrm{CPF} \\
\text { B.Wt }\end{array}$ & $3.91 \pm 0.06^{* \$ \#}$ & $6.83 \pm 0.25^{* \#}$ & $\begin{array}{l}41.36 \pm \\
1.80 *^{\$ \#}\end{array}$ & $11.49 \pm 0.18^{* \$ \#}$ \\
\hline IV & $\begin{array}{l}2 \mathrm{~g} / \mathrm{Kg} \text { TC B.Wt } \\
+30 \mathrm{mg} / \mathrm{Kg} \mathrm{CPF} \\
\text { B.Wt }\end{array}$ & $4.87 \pm 0.13^{* \$ \#}$ & $8.33 \pm 0.31 *^{\$ \#}$ & $\begin{array}{l}51.96 \pm \\
0.73^{\$ \#}\end{array}$ & $14.13 \pm 0.36^{* \$ \#}$ \\
\hline V & $\begin{array}{l}4 \mathrm{~g} / \mathrm{Kg} \text { TC B.Wt } \\
+30 \mathrm{mg} / \mathrm{Kg} \mathrm{CPF} \\
\text { B.Wt }\end{array}$ & $6.53 \pm 0.33^{\$}$ & $11.67 \pm 0.33^{\$ \#}$ & $\begin{array}{l}62.00 \pm \\
1.51 *^{\$ \#}\end{array}$ & $16.72 \pm 1.08^{* \#}$ \\
\hline VI & $4 \mathrm{~g} / \mathrm{Kg}$ TC B.Wt & $5.79 \pm 0.14^{* \$}$ & $13.01 \pm 0.39 *^{\$}$ & $\begin{array}{l}71.59 \pm \\
1.82 * \$\end{array}$ & $18.34 \pm 0.38 * \$$ \\
\hline
\end{tabular}

Values are mean \pm S.D. of 6 animals in each group. $\mathrm{p} \leq 0.05$ was considered significant.

* Significantly different from control group ( $\left.{ }^{*} \mathrm{p} \leq 0.05\right)$.

\$ Significantly different from $30 \mathrm{mg}$ CPF/Kg B.Wt. group $(\$ p \leq 0.05)$.

${ }^{\#}$ Significantly different from $4 \mathrm{~g} \mathrm{TC} / \mathrm{Kg} \mathrm{B}$.Wt group $\left({ }^{\#} \mathrm{p} \leq 0.05\right)$.

Several earlier studies have suggested abnormalities in erythrocyte shape following OP exposure (Singh and Srivastava, 2010). Distortions of normal discocytes to different pathological forms were observed after $\mathrm{CPF}$ exposure. Most of the erythrocytes became spherocytes and some prominent changes such as appearance of irregular margins, central and peripheral protuberances, distorted shape were observed after CPF treatment for 28 days. A scanning electron micrograph of erythrocytes of $\mathrm{CPF}+\mathrm{TC}$ at high dose (Fig. 1G) shows improved erythrocyte topography as compared with CPF treated group.

Studies on the morphological feature of cellular elements have great importance for assessing their functional state, vitality and kinetics. Observed alterations in the shape of normal RBC's might be due to changes in lipid composition of the membrane (Kumar, 1993).

It can be concluded from the present studies that CPF induced toxic effects on liver and erythrocytes in terms of antioxidant, biochemical and morphological alterations. The mechanism appears to be mediated through increased oxidative stress and compromised antioxidant ability of the cell, which led to alterations in membrane composition and function, ultimately resulting in altered morphology. Treatment with $\mathrm{TC}$ resulted in amelioration in $\mathrm{CPF}$ induced antioxidant, biochemical and morphological changes, suggesting that TC supplementation to individuals exposed to $\mathrm{CPF}$ as well as other OP pesticides would be beneficial. Although TC is having therapeutic potential for treatment of $\mathrm{CPF}$ like pesticides involving oxidative stress 
mediated neuronal dysfunctions, but the precise mechanisms of its protective action remains to be explored further.

\section{References}

Aggarwal, K. and Singh, D. 2011. Toxicological effects of chlorpyrifos on lipid peroxidation and inhibition of some liver enzymes in rat. Pun. Acad. Sci., 7-8 (1and 2): 32-38.

Aggarwal, K. and Singh, D. 2014. Studies on the effect of oxidative stress induced by chlorpyrifos on antioxidant hepatic enzymes in rat. World J. Pharm. Pharm. Sci., 3(11): 523-533.

Agrahari, S. and Gopal, K. 2008. Inhibition of $\mathrm{Na}^{+} / \mathrm{K}^{+}$-ATPase in different tissues of freshwater fish Channa punctatus (Bloch) exposed to monocrotophosq. Pest. Biochem. Physiol., 92: 57-60.

Amara, I.B., Soudani, N., Hakim, A., Troudi, A., Zeghal, K.M., Boudawara, T. and Zeghal, N. 2011. Selenium and vitamin E, natural antioxidants, protect rat cerebral cortex against dimethoate-induced neurotoxicity. Pest. Biochem. Physiol., 101: 165-174.

Amitai, G., Moorad, D., Adani, R. and Doctor, B.P. 1998. Inhibition of acetylcholinesterase and butyrylcholinesterase by chlorpyrifos-oxon. Biochem. Pharmacol., 56: 293-299.

Attia, A.A., ElMazoudy, R.H. and ElShenawy, N.S. 2012. Antioxidant role of propolis extract against oxidative damage of testicular tissue induced by insecticide chlorpyrifos in rats, Pest. Biochem. Physiol., 103: 87-93.

Badar, V.A., Thawani, V.R., Wakode, P.T., Shrivastava, M.P., Gharpure, K.J., Hingorani, L.L. and Khiyani, R.M.
2005. Efficacy of Tinospora cordifolia in allergic rhinitis. $J$. Ethnopharmacol., 96(3): 445-449.

Bagchi, M. and Stohs, S.J. 1993. In vitro induction of reactive oxygen species by $2,3,7,8$,-tetrachlorodibenzo- $p$ dioxin, endrin, and lindane in rat peritoneal macrophages and hepatic mitochondria and microsomes. Free Rad. Biol. Med., 14: 11-18.

Barski, D., Spodniewska, A. and Zasadowski, A. 2011. Activity of superoxide dysmutase, catalase and glutathione peroxidase in rats exposed to chlorpyrifos and erofloxacin. Pol. J. Vet. Sci., 14(4): 523-529.

Bishayi, B., Roychowdhury, S., Ghosh, S. and Sengupta, M. 2002. Hepatoprotective and immunomodulatory properties of Tinospora cordifolia in $\mathrm{CCl}_{4}$ intoxicated mature albino rats. $J$. Toxicol. Sci., 27(3): 139-146.

Buege, J.A. and Aust, S.D. 1978. Microsomal lipid peroxidation. In: Methods in Enzymology, (S Fleischer and L. Packer) Acad Press, New York and London. 52: 302-310.

Carlberg, I. and Mannervik, B. 1985. Glutathione reductase Methods in Enzymology. Academic Press New York 113: 484-490.

Chamber, H.W. and Chamber, J.E. 1989. An investigation of acetylcholinesterase inhibition and ageing, and choline acetyltransferase activity following a high-level acute exposure to paraoxon. Pest. Biochem. Physiol., 33: 125-131.

Chambers, J.E. and Carr, R.L. 1993. Inhibition patterns of brain acetylcholinesterase and hepatic and plasma aliesterases following exposures to three phosphorothionate insecticides and their oxonsin rats. 
Fundam. Appl. Toxicol., 21: 111-119. Chelikani, P., Fita, I. and Loewen, P.C. 2004. Diversity of structures and properties among catalases. Cell Mol. Life Sci., 61(2): 192-208.

Costa, L.G. and Murphy, S.D. 1983. Unidirectional cross-tolerance between the carbamate insecticide propoxur and the organophosphate disulfoton in mice. Fund. App. Toxicol., 3(5): 483-488.

Costa, L.J., Schwab, B.W. and Murphy, S.D. 1982. Tolerance to anticholinesterase compounds in mammals. Toxicol., 25: 79-97.

Demir, F., Uzun, F.G., Durak, D. and Kalender, Y. 2011. Subacute chlorpyrifos-induced oxidative stress in rat erythrocytes and the protective effects of catechin and quercetin. Pest. Biochem. Physiol., 99(1): 7781.

Diab, A.E.A., El-Aziz, E.A.A., Hendawy, A.A., Zahra, M.H. and Hamza, R.Z. 2012. Antioxidant Role of both Propolis and Ginseng against Neurotoxicity of Chlorpyrifos and Profenofos in Male Rats. Life Sci. J. 9(3): 987-1008.

Ellman, G.L., Courtney, D., Andres, V. and Featherston, R.M. 1961. A new and rapid colorimetric determination of acetylcholinesterase activity. Biochem. Pharmacol. 7: 88-95.

El-sharkawy, E.E., Yahia, D. and El-Nisr, N.A. 2012. Chlorpyrifos induced testicular damage in rats: Ameliorative effect of glutathione antioxidant. J. Amer. Sci., 8(7): 708716.

El-Shenawy, N.S., El-Salmy, F., Al-Eisa, R.A. and El-Ahmary, B. 2010. Amelioratory effect of vitamin $\mathrm{E}$ on organophosphorus insecticide diazinon-induced oxidative stress in mice liver. Pest. Biochem. Physiol.,
96: 101-107.

Fornazier, R.F., Ferreira, R.R., Vitoria, A.P., Molina, S.M.G., Lea, P.J., Azevedo, R.A (2002) Effects of cadmium on anti-oxidant enzyme activities in sugar cane. Biol. Plant, 45:91-97

Fukuto, T.R. 1990. Mechanism of action of organophosphorus and carbamate insecticides. Environ. Health Perspect., 87: 245-254.

Goel, A., Danni, V. and Dhawan, D.K. 2005. Protective effects of zinc on lipid peroxidation, antioxidant enzymes and hepatic histoarchitecture in chlorpyrifosinduced toxicity. Chem. Biol. Interact., 156:131-40.

Goel, H.C., Kumar, P.I. and Rana, S.V. 2002. Free radical scavenging and metal chelation by Tinospora cordifolia, a possible role in radioprotection. Indian J. Exp. Biol., 40(6): 727-734.

Goel, H.C., Prasad, J. and Singh, S. 2004. Radioprotective potential of an herbal extract of Tinospora cordifolia. J. Radiat. Res., 45: 61-68.

Heikal, T., Abdel-Tawab, M., Mossa, H., Abdel-Rasoul, M.A. and Mare, G.K. 2013. The Ameliorating effects of green tea extract against cyromazine and chlorpyrifos induced liver toxicity in male rats. Asian $J$. Pharma. and Clin. Res., 6(1): 974.

Hexum, T.D. and Fried, R. 1979. Effect of superoxide radicals on $\left(\mathrm{Na}^{+}, \mathrm{K}^{+}\right)$ transport adenosine triphosphatase and protection by superoxide dismutase. Neurochem. Res., 4: 7392.

Horn, H.D. 1971. Glutathione reductase In: Methods of enzymatic analysis. Bergmeyer, H.V. (Ed.) Academic Press, New York, 857-881.

Jagetia, G.C., Nayak, V. and Vidyasagar, M.S. 1998. Evaluation of the 
antineoplastic activity of guduchi Tinospora cordifolia in cultured HeLa cells. Cancer Letters, 127(1-2): 71.

Khalifa, F.K., Fatma, A., Khalil, H.A., Barakat, M. and Hassan, M. 2011. Protective Role of Wheat Germ and Grape Seed Oils in ChlorpyrifosInduced Oxidative Stress, Biochemical and Histological Alterations in Liver of Rats. Aust. $J$. Basic and App. Sci. 5(10): 54-66.

Khan, M., Sobti, R.C. and Kataria, L. 2005. Pesticide-induced alteration in mice hepato-oxidative status and protective effects of black tea extract. Clinica Chimica Acta, 358(1-2): 131138.

Kono, Y. 1978. Generation of superoxide radical during autooxidation of hydroxylamine and an assay for superoxide dismutase. Arch. Biochem. Biophys., 186: 189-195.

Kumar, V.V. 1993. Lipid molecular shapes and membrane architecture. Indian J. Biochem. Biophys., 30: 135-138.

Kwong, T.C. 2002. Organophosphate pesticides: biochemistry and clinical toxicology. Ther. Drug Monit., 24: 144-149.

Leaberry, A.L. 1986. Ambient water quality criteria for Chloropyrifos, United State Environmental Protection Agency (EPA) Report, US, Washington, DC

Linhart, K. and Walter, K. 1965. Phosphatase (phosphomono esterases); In: Methods of Enzymatic Anlaysis. Bergmeyer, H.V. (Ed.) Academic Press New York and London 944.

Liochev, S.I. and Fridovich, I. 2003. Mutant $\mathrm{Cu}, \mathrm{Zn}$ superoxide dismutases and familial amylotrophic lateral sclerosis: evaluation of oxidative hypotheses. Free Radic. Biol. Med.,
34: 1383-1389.

Lowry, O.H., Rosenbrough, N.J., Farr, A.I. and Randall, R.J. 1951. Protein measurement with folin phenol reagent. J. Biol. Chem., 239: 23702385.

Luck, H. 1971. Catalase. In: Bergmeyer, H.U. (Ed.) Methods of Enzymatic Analysis. New York: Academic Press, 885-894.

Mansour, S.A. and Mossa, A.H. 2009. Lipid peroxidation and oxidative stress in rat erythrocytes induced by chlorpyrifos and the protective effect of zinc. Pest. Biochem. Physiol., 93: 34-39.

Mansour, S.A. and Mossa, A.H. 2010. Oxidative damage, biochemical andhistological alterations in rats exposed to chlorpyrifos and theantioxidant role of zinc. Pest Biochem. Physiol., 96: 14-23.

Mathew, S. and Kuttan, G. 2003. Antioxidant activity of Tinospora cordifolia and its usefulness in the amelioration of cyclophosphamide induced toxicity. J. Exp. Clin. Cancer Res., 16(4): 407-11.

Mishra, O.P., Delivoria-Papadpoulos, M., Cahillane, G. and Wagerle, L.C. 1989. Lipid peroxidation as the mechanism of modification of the affinity of the $\mathrm{Na}^{+}, \mathrm{K}^{+}$-ATPase active sites for ATP, $\mathrm{Na}^{+}, \mathrm{K}^{+}$and strophanthidin in vitro. Neurochem. Res., 14: 845-851.

Miyazaki, S. and Hodgson, G.C. 1972. Chronic toxicity of dursban and its metabolite 3,5,6-trichloro-2-pyridinol in chickens. Toxicol. Appl. Pharmacol., 23: 391-398.

Nagarkatti, D.S., Rege, N.N., Desai, N.K. and Dahanukar, S.A. 1994. Modulation of Kupffer cell activity by Tinospora cordifolia in liver damage. J. Postgrad. Med., 40(2): 
65-67.

Niki, F., Yamamoto, Y., Takahashi, M., Yamamoto, K., Komuro, E., Miki, M., Yasuda, H. and Mino, M. 1988. Free radical-mediated damage of blood and its inhibition by antioxidants. J. Nutr. Sci. Vitaminol., 34: 507-12.

Quigley, J.P. and Gotterer, G.S. 1969. Distribution of $\left(\mathrm{Na}^{+}-\mathrm{K}^{+}\right)$stimulated ATPase activity in rat intestinal mucosa. Biochem. Biophys. Acta, 173: 456-468.

Richardson, R.J. 1995. Assessment of the neurotoxic potential of chlorpyrifos relative to other organophosphorus compounds: A critical review of the literature. J. Toxicol. Environ. Health, 44: 135-165.

Saxena, R., Garg, P. and Jain, D.K. 2011. In Vitro anti-oxidant effect of vitamin $\mathrm{E}$ on oxidative stress induced due to pesticides in rat erythrocytes. Toxicol. Internat., 181: 73-76.

Schatz, L. and Segal, H.L. 1969. Reduction of alpha - ketoglutarate by homogenous lactic acid dehydrogenase - $\mathrm{X}$ of testicular tissue. J. Biol. Chem., 244: 43934397.

Shittu, M., Ayo, J.O., Ambali, S.F., Fatihu, M.Y., Onyeanusi, B.I. and Kawu, M.U. 2012. Chronic chlorpyrifosinduced oxidative changes in the testes and pituitary gland of Wistar rats: Ameliorative effects of vitamin C. Pest. Biochem. Physiol., 102: 7985.

Shivananjappa, M.M. and Muralidhara, S. 2012. Abrogation of maternal and fetal oxidative stress in the streptozotocin-induced diabetic rat by dietary supplements of Tinospora cordifolia. Nutrition, 28(5): 581-587.

Siesms, W.G., Sommerburg, C., John, S., Van, K. and Frederick, J.G.M. 2000.
Carotenoid oxidative degradation products inhibit $\mathrm{Na}^{+} / \mathrm{K}^{+}$-ATPase. Free Rad. Res., 3: 427-435.

Singh, N.N. and Srivastava, A.K. 2010. Haematological parameters as bioindicators of insecticide exposure in teleosts. Ecotoxicology, 19: 838854.

Singh, R.P., Banerjee, S., Kumar, P.V.S., Raveesha, K.A. and Rao, A.R. 2006. Tinospora cordifolia induces enzymes of carcinogen/drug metabolism and antioxidant system and inhibits lipid peroxidation in mice. Phytomed., 13(1-2): 74-84.

Stanely, P.M., Prince, P. and Menon, V.P. 1999. Antioxidant activity of Tinospora cordifolia roots in experimental diabetes. $J$. Ethnopharmacol. 65 (3): 277-281.

Stanely, P.M., Prince, P. and Menon, V.P. 2000. Hypoglycemic and other related actions of Tinospora cordifolia roots in alloxan induced diabetic rats. J. Ethnopharmacol. 70: 9-15.

Subramanian, M., Chintalwar, G.J. and Chattopadhyay, S. 2002. Antioxidant properties of a Tinospora cordifolia polysaccharide against iron-mediated lipid damage and $\gamma$-ray induced protein damage. Redox Report, 7(3): 137-143.

Sun, A.Y. 1972. The effect of lipid peroxidation on synaptosomal $\left(\mathrm{Na}^{+}\right.$, $\mathrm{K}^{+}$)- ATPase isolated from the cerebral cortex of squirrel monkey. Biochem. Biophys. Acte 266: 350-60.

Taylor, P., Gilman, G.A., Rail, T.W., Nies, A.S. and Taylor, P. 1990. Anticholinesterase agents; In: The pharmacological Basis of therapeutics. Pergamon Press Inc New-York 131-147.

Thenmozhi, C., Vignesh, V., Thirumurugan, R. and Arun, S. 2011. Impacts of 
Malathion on mortality and biochemical changes of fresh water fish labeo rohita. Iran J. Environ. Health Sci. Eng., 8(4): 387.

Verma, R.S., Mehta, A. and Srivastava, N. 2007. In vivo chlorpyrifos induced oxidative stress: attenuated by antioxidant vitamins. Pest Biochem. Phys., 88: 191-196.

Wadood, A., Wadood, N. and Shah, S.A. 1989. Effects of Acacia arabica and Caralluma edulis on blood glucose levels on normal and alloxan diabetic rabbits. J. Pak. Med. Assoc., 39: 208212.

Wu, H., Zhang, R.J., Liu, J., Guo, Y. and Ma, E. 2011. Effects of malathion and chlorpyrifos on acetylcholinesterase and antioxidant defense system in Oxya chinensis (Thunberg) (Orthoptera: Acrididae). Chemosphere, 83(4): 599-604.

Yamano, T. and Morita, S. 1992. Hepatotoxicity of trichlorphon and dichlorvos in isolated rat hepatocytes. Toxicology, 76: 69-77.

Yonar, M., Mis, E.S., Yonar, M., Ural, S.E., Silici, S. and Düsükcan, M. 2012. Protective role of propolis in chlorpyrifos-induced changes in the haematological parameters and the oxidative/antioxidative status of Cyprinus carpio carpio. Food Chem. Toxicol., 50: 2703-2708.

\section{How to cite this article:}

Kanika Aggarwal and Devinder Singh. 2016. The Role of Tinospora cordifolia in Extenuating the Toxic Effects of CPF on Hepatic Modifications along with Electron Microscope Observations in Red Blood Cells. Int.J.Curr.Microbiol.App.Sci. 5(10): 952-967. doi: http://dx.doi.org/10.20546/ijcmas.2016.510.102 